\title{
KARAKTERISTIK PERILAKU CALON PENUMPANG KERETA PRAMEKS DI RUANG TUNGGU STASIUN PURWOSARI
}

\author{
Abid Fathin Fakhri \\ Mahasiswa Program Studi Arsitektur \\ Fakultas Teknik Universitas \\ Muhammadiyah Surakarta \\ e-mail: fafaaff69@gmail.com
}

Muhammad Siam Priyono Nugroho Dosen Program Studi Arsitektur Fakultas Teknik Universitas Muhammadiyah Surakarta

e-mail: m_siam@ums.ac.id

\begin{abstract}
ABSTRAK
Stasiun Purwosari merupakan stasiun kereta api kelas besar yang terletak di Purwosari, Laweyan, Surakarta. Stasiun Purwosari termasuk dalam Daerah Operasi VI Yogyakarta, dan hanya melayani KA kelas ekonomi lintas selatan dan lokal/komuter. Stasiun ini dibangun pada tahun 1875, dan merupakan stasiun tertua di Surakarta. Pembangunannya ditangani oleh NederlandsIndische Spoorweg Maatschappij. Ruang tunggu Stasiun Purwosari adalah tempat yang menarik untuk diteliti, karena ruang tunggu merupakan tempat berkumpul banyak orang dari berbagai tempat asal dan berbagai empat tujuan, dan berbagai alasan untuk melakukan perjalanan dengan kereta api. Penelitian ini bertujuan untuk mengetahui karakteristik perilaku dan pola sirkulasi calon penumpang kereta Prameks pada ruang tunggu Stasiun Purwosari. Metode penelitian yang digunakan yaitu metode kualitatif dimana lebih menekan aspek-aspek pemahaman secara mendalam terhadap suatu permasalahan untuk generalisasi penelitian, setelah perilaku dapat direkam dan digambarkan melalui behavioral mapping, selanjutnya dapat dipetakan perilaku berdasarkan hasil pengamatan selama di lapangan. Karakteristik perilaku akan terbentuk melalui amatan terhadap aktivitas yang berulang, dan dikategorikan dalam temuan penelitian yang kemudian disajikan dalam skema, tabel dan persentase. Hasil penelitian menunjukkan bahwa karakteristik perilaku dimana calon penumpang lebih banyak menghabiskan waktunya bermain Smartphone untuk menunggu kereta datang, dan adanya kecenderungan calon penumpang memadati jalur sirkulasi ruang tunggu pada sisi timur.
\end{abstract}

KATA KUNCI: kereta Prameks; karakteristik perilaku; Stasiun Purwosari

\section{PENDAHULUAN \\ Latar Belakang}

Transportasi umum berperan penting dalam kemajuan ekonomi sebuah kota dan merupakan salah satu sarana penting dalam menunjang kemajuan pembangunan nasional serta mempengaruhi hampir setiap aspek kehidupan. Kebutuhan masyarakat akan sarana transportasi umum meningkat, seiring dengan meningkatnya pertumbuhan penduduk dan perekonomian di Indonesia. Jasa transportasi umum merupakan hal pokok dalam kehidupan sehari-hari, untuk mempermudah dan memperlancar semua kegiatan. Pemerintah berkewajiban turut andil dalam penyediaan fasilitas transportasi umum ini untuk melayani masyarakat (public service). Transportasi dibutuhkan untuk menghubungkan satu daerah ke daerah lain dengan waktu yang efektif. Tanpa adanya perusahaan jasa yang terkelola dengan baik maka distribusi barang dari produsen ke konsumen akan mengalami hambatan. Begitu pula masyarakat yang ingin bepergian ke luar daerah ataupun luar kota akan mengalami kesulitan, bila tidak ada jasa transportasi umum.
Stasiun Purwosari merupakan stasiun kereta api kelas besar yang terletak di Purwosari, Laweyan, Surakarta . Stasiun Purwosari termasuk dalam Daerah Operasi VI Yogyakarta dan hanya melayani KA kelas ekonomi lintas selatan dan lokal/komuter. Stasiun ini dibangun pada tahun 1875 dan merupakan stasiun tertua di Surakarta. Pembangunannya ditangani oleh Nederlands-Indische Spoorweg Maatschappij - NISM (Harjono, 2016).

Stasiun Purwosari dibangun saat pemerintahan Hindia Belanda, sehingga memiliki desain arsitektur colonial, hampir sama dengan Stasiun Willem I di Ambarawa dan Stasiun Kedungjati di Grobogan Purwodadi. Seiring berjalannya waktu dan kebutuhan akan adanya beberapa fasilitas tambahan, Stasiun Purwosari melakukan renovasi, seperti penambahan ruang untuk area ruang tunggu calon penumpang, loket pembelian tiket, penambahan gedung parkir motor pada area parkir, dan juga perluasan peron. Renovasi besar-besaran tidak merubah disain asli.

Salah satu perubahan yang berpengaruh terhadap perilaku calon penumpang adalah perluasan area peron kereta api di sisi barat stasiun. Perluasan peron menyebabkan penumpukan calon penumpang 
yang menunggu kedatangan kereta api, khusunya kereta lokal/jarak dekat seperti kereta api Prameks. Calon penumpang Prameks termasuk terbanyak dalam setiap harinya, disebabkan jadwal kereta api Prameks yang cukup padat, rata-rata setiap 1 jam sekali kereta api Prameks siap membawa penumpang hingga Yogyakarta bahkan Kutoarjo.

Ruang tunggu Stasiun Purwosari merupakan ruang terbuka, dengan penutup atap disangga tiang tiang besi yang tinggi. Disain ruang tunggu ini membuat udara mengalir dengan leluasa dari segala penjuru. Ruang tunggu yang lebih luas dan terbuka ada di sisi timur stasiun, sementara ruang tunggu itu menjadikan para calon penumpang kereta Prameks memiliki kebiasaan menunggu kereta di bagian barat ruang tunggu Stasiun Purwosari yang membuat bagian barat stasiun penuh sehingga sebagian besar calon penumpang tidak mendapatkan tempat duduk atau terpaksa menunggu di area timur yang lebih jauh dari peron pemberhentian kereta Prameks.

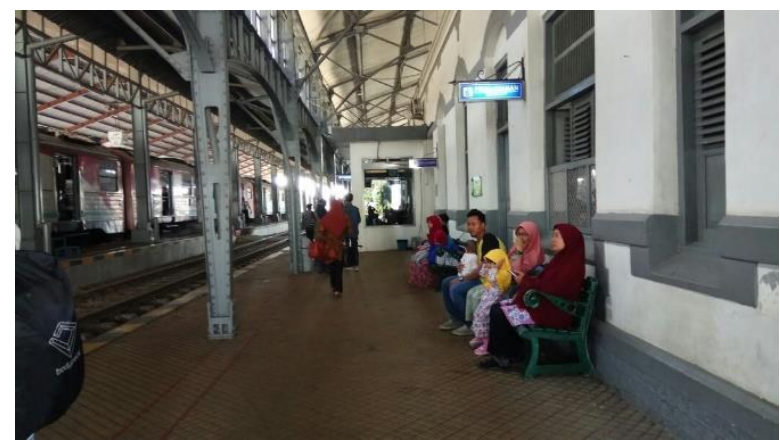

Gambar 1. Calon penumpang di Stasiun Purwosari (sumber: dokumen penulis, 2018)

\section{Rumusan Masalah}

Calon penumpang kereta api Prameks, baik secara kuantitas dan kualitas menarik untuk diamati dan diteliti, karena penumpukan calon penumpang pada jam-jam tertentu di ruang tunggu pastinya akan memberikan pengaruh kenyamanan pada mereka. Calon penumpang akan melakukan aktivitas yang dianggapnya nyaman bagi dirinya. Berdasarkan hal itu muncul permasalahan penelitian sebagai berikut: Bagaimana pola aktivitas dan perilaku calon penumpang kereta Prameks di area ruang tunggu?

\section{Manfaat Penelitian}

Penelitian tentang perilaku sudah banyak dilakukan, namun perilaku calon penumpang kereta api Prameks tampaknya belum banyak dilakukan, sehingga hasil penelitian ini memberikan manfaat khususnya bagi pengelola stasiun, agar memberikan sarana dan prasarana yang memadai bagi para calon penumpang selama masa menunggu jadwal keberangkatan.

\section{TINJAUAN PUSTAKA}

Stasiun kereta api Indonesia yang kebanyakan merupakan benda cagar budaya, memiliki nilai lebih untuk bisa dikembangkan lebih lanjut ke arah wisata edukasi berkaitan dengan sejarah bangsa. Pada kisaran tahun 2010-2015 ini cukup banyak program revitalisasi stasiun cagar budaya yang sedang ramai dicanangkan oleh pemerintah-pemerintah kota di Indonesia. Hal ini diharapkan dapat memberi pilihan lain selain mengembangkan stasiun ke arah tujuan komersial namun juga harus bisa mengedukasi masyarakat pengguna. Pemerintah memperhatikan revitalisasi stasiun-stasiun lama yang masih bisa dioperasionalkan sehingga layanan operasi penumpang bisa semakin meningkat.

Stasiun Purwosari adalah stasiun tertua di Surakarta, berdiri tahun 1875. Dalam sejarahnya, Stasiun Purwosari memiliki jalur percabangan kereta api arah Yogyakarta, Wonogiri, dan Boyolali. Namun, hanya jalur arah Yogyakarta yang masih aktif sebagai jalur utama dan arah Wonogiri sebagai jalur sekunder yang berdampingan langsung dengan Jalan Slamet Riyadi melewati tengah Kota Surakarta. Sedangkan, jalur kereta arah Boyolali sudah tidak aktif dan sudah beralihfungsi sebagai jalur pedestrian atau jalur hijau dan di beberapa titik beralihfungsi sebagai bangunan kios-kios pedangang. Percabangan arah kereta api membuat penumpukan calon penumpang di ruang tunggu. Apalagi jalur kereta ke Yogyakarta yaitu Kereta api Prambanan Ekspres (Prameks) yang pertamakali diluncurkan tanggal 20 Mei 1994, memiliki jadwal padat 10 kali pemberangkatan dalam 1 hari.

Stasiun tidak hanya berfungsi untuk tempat naik dan turunnya penumpang. Di stasiun dapat dilakukan kegiatan usaha penunjang angkutan kereta api seperti usaha pertokoan, restoran, perkantoran, perhotelan (UU No.13 Tahun 1992). Kebijakan ini mengundang adanya fungsi komersial di stasiun. Namun semua fasilitas tidak akan berfungsi optimal bila tidak didukung adanya ruang tunggu bagi calon penumpang. Ruang tunggu harus memberikan rasa nyaman bagi calon penumpang. Umumnya calon penumpang akan merasa lebih tenang apabila posisi menunggu lebih dekat dengan jalur kereta api yang nanti akan dinaikinya. Perasaan penumpang yang sama menyebabkan penumpukan calon penumpang di ruang tunggu yang dekat dengan jalur kereta api. Penumpukan penumpang sebenarnya mempersempit ruang personal mereka.

Ruang personal akan menyempit dengan kondisi kepadatan tinggi. Jenis kelamin tidak lagi menjadi masalah. Himawan (2018) meneliti ruang tunggu Stasiun Gubeng Surabaya, dikatakan bahwa ruang tunggu akan terganggu kenyamanannya apabila ada penyepitan ruang personal di ruang tunggu. Persepsi 
calon penumpang beragam dalam menanggapi ketidaknyamanan. Penumpang mempersepsikan ketidaknyamanan melalui indra pendengaran, peraba dan penciuman. Lain halnya dengan adanya pendapat bahwa ketidaknyamanan di sebuah ruang tunggu karena adanya reduksi tingkat pencahayaan, yang menyebabkan rasa takut, cemas dan sebagainya.

Pendekata perilaku diperlukan untuk melihat lebih jauh pilihan aktivitas seseorang, manakala ruang personalnya semakin menyempit. Pendekatan ini melihat bahwa aspek-aspek norma, kultur, psikologi masyarakat yang berbeda akan menghasilkan konsep dan wujud ruang yang berbeda pula (Rapoport,1977). Secara konseptual, pendekatan perilaku menekankan bahwa manusia merupakan makhluk berpikir yang mempunyai presepsi dan keputusan dalam interaksinya dengan lingkungan. Konsep meyakini bahwa interaksi antar manusia dan lingkungan tidak dapat diinterpretasikan secara sederhana melainkan kompleks, dimana ada proses kognitif (cognitive process) yakni proses memberi arti dan pemaknaan ruang dimana menggunakan pengetahuan ecological psycology.

Pendekatan perilaku menggunakan teknik pendataan pemetaan perilaku (behavioural mapping). Teknik pemetaan perilaku akan memperoleh informasi fenomena yang terkait antara perilaku dan system spasialnya. Sommer (1986) mengatakan bahwa teknik pemetaan perilaku ini menggunakan sketsa-sketsa yang akan menemukan identifikasi perilaku dan frekwensi perilaku.

Pemetaan lain adalah terhadap tempat. Fokus pemetaan ini adalah pada tanda-tanda di sebuah tempat, dimana dapat mengidentifikasi aktivitas apa yang telah terjadi di tempat tersebut.

\section{METODE PENELITIAN}

Penelitian ini bersifat kajian studi observasi. Metode penyajian yang digunakan dalam penelitian ini adalah deskriptif kualitatif. Penelitian ini dilakukan untuk meggambarkan (mendeskripsikan) aktivitas yang terjadi pada ruang tunggu Stasiun Purwosari.

Motivasi utama penelitian ini adalah untuk menemukan suatu penjelasan terhadap aktivitas yang terjadi pada ruang tunggu. Dalam penelitian ini peneliti hanya mengumpulkan data, mengolah, mengamati, mencatat dan mendeskripsikan hasilhasil penelitian. Pendekatan deskriptif dilakukan untuk menggambarkan dan menginterpretasikan obyek studi yaitu untuk mengetahui dan mendalami penggunaan ruang tunggu Stasiun Purwosari oleh calon penumpang Kereta Prameks. Kepadatan ruang tunggu tergantung jam puncak penumpang, karena ini berkaitan juga dengan jumlah gerbong tersedia. Jumlah gerbong pada tiap pemberangkatan 3-5 buah, dengan keberangkatan 05:17 WIB, 07:27 WIB, 09:17
WIB, 10:47 WIB, 12:22 WIB, 13:14 WIB, 14:07 WIB, 15:48 WIB, 16:18 WIB, 18:10 WIB, dan 18:47 WIB. Penelitian ini mengambil jam puncak 07:27 sampai 09:17 WIB.

Terdapat empat dimensi dalam melakukan studi perilaku-lingkungan antara lain; pelaku, aktivitas, tempat (ruang), dan waktu. Untuk memenuhi unsurunsur tersebut penelitian ini menggunakan metode behavioral mapping (pemetaan perilaku).

Perilaku yang sudah direkam dan digambarkan selanjutnya dipetakan berdasarkan hasil pengamatan selama di lapangan. Setiap aktivitas yang berulang dan membentuk suatu (pola) perilaku tertentu akan dikategorikan sebagai temuan penelitian.

Langkah-langkah yang dilakukan dalam proses observasi (behavorial mapping) dalam penelitian ini adalah:

1. Peneliti menggunakan peta dasar yang telah dibuat untuk memberikan gambaran lokasi area ruang tunggu.

2. Peneliti membuat dan memetakan daftar perilaku yang akan diamati.

3. Dalam suatu kurun waktu penelitian, peneliti mencatat berbagai perilaku yang terjadi pada masing-masing tempat.

4. Data hasil dari pencatatan tersebut kemudian dijelaskan melalui deskripsi data dan disertai dengan foto.

5. Data aktivitas/perilaku yang telah terdeskripsikan di masing-masing lokasi area observasi diklasifikasikan ke dalam temuan pola perilaku yang paling umum/sering terjadi.

\section{Pengumpulan dan Pencatatan Data}

Data kualitatif dianalisis untuk memahami situasi dan kondisi objek penelitian menjadi bagianbagian, hubungan antar bagian, dan hubungannya dengan keseluruhan.

Instrumen dan teknik pengumpulan data dalam penelitian ini antara lain: observasi dan dokumentasi. Observasi dilakukan dengan pengamatan langsung terhadap subjek ketika berada di ruang tunggu Stasiun Purwosari. Data aktivitas calon Penumpang yang telah diperoleh melalui observasi kemudian dicatat dan diklasifikasikan berdasarkan jenis-jenis aktivitas/perilaku.

Metode behavorial mapping sangat perlu memperhatikan ruang dan waktu. Oleh karena itu, segala bentuk pencatatannya melampirkan ruang (lokasi) dan waktu sebagai salah satu tolak ukur validitas data.

\section{Langkah Pendataan}

1. Memetakan pola sirkulasi calon penumpang di tiga bagian ruang tunggu Stasiun Purwosari pada saat peak hour. 
2. Observasi pola perilaku yang terjadi sesuai daftar yang sudah dibuat.

3. Mengelompokkan perilaku calon penumpang.

4. Membuat skema dari pola pergerakan dan perilaku yang terjadi.

5. Mengambil beberapa sample calon penumpang untuk pola perilaku yang paling banyak terjadi.

\section{Analisis Data}

Pemetaan perilaku melalui pengamatan pola aktivitas dan pergerakan yang terjadi di ruang tunggu, diperoleh data untuk menggambarkan bagaimana ruang tunggu tersebut digunakan oleh calon penumpang.

Penafsiran data dalam penelitian dilakukan dengan cara sebagai berikut:

1. Mengidentifikasi aktivitas dan jumlah calon penumpang di setiap bagian ruang tunggu

2. Memaparkan penggunaan atau aktivitas calon penumpang pada ruang tunggu berdasarkan rentang waktu tertentu.

3. Menunjukkan kaitan antara pola perilaku calon penumpang dengan ruang tunggu serta fasilitasfasilitas lain di dalamnya.

\section{HASIL DAN PEMBAHASAN}

\section{Pengamatan Stasiun Purwosari}

Survey dilakukan selama 5 hari pada peak hours, keberangkatan pagi 07:27 sampai jam 09:17 WIB, survey pemetaan pola perilaku dilakukan pada area peron 1 di area ruang tunggu pada jam sibuk.

Ruang tunggu utama berada di peron 1, sedangkan jalur pemberhentian kereta Prameks berada di jalur/peron 3 bagian tengah. Ada beraneka ragam kegiatan yang terjadi di area ruang tunggu Stasiun Purwosari, seperti mengisi daya smartphone, tidur, dan sebagainya.

Pemetaan pola aktivitas membagi zona ruang tunggu menjadi 3 bagian sesuai gambar 2: (1) bagian Timur, (2) bagian Tengah dan (3) bagian Barat.

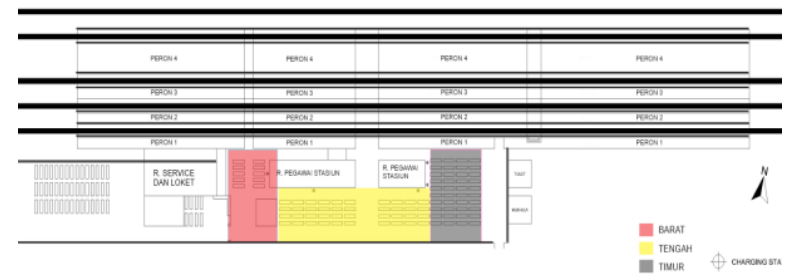

Gambar 2. Skema Zona Ruang Tunggu (sumber: Data penulis, 2018)

Ruang tunggu penumpang yang diamati adalah ruang tunggu yang terdapat di dalam stasiun, setelah penumpang melewati pintu pemeriksaan tiket. Bagian barat adalah paling dekat dengan pintu masuk atau pintu pemeriksaan tiket atau boarding pass. Aktivitas atau pola sirkulasi yang teramati sejak melewati pintu pemeriksaan hingga duduk, terpetakan sebagaimana gambar 3 berikut:

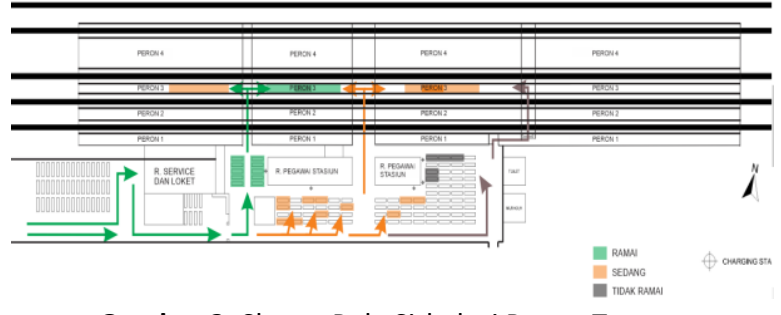

Gambar 3. Skema Pola Sirkulasi Ruang Tunggu (sumber: Data penulis, 2018)

Hasil pengamatan perilaku, ditemukan bahwa calon penumpang kereta Prameks lebih memilih duduk di ruang tunggu bagian barat, sehingga ruang tunggu bagian barat lebih padat/ramai. Sedangkan pada bagian tengah terdapat beberapa calon penumpang yang tersebar mengisi kursi yang kosong, sehingga agak sedikit padat. Pada bagian timur, yang jaub dari pintu masuk, hanya di temukan sedikit calon penumpang, dan cenderung mengisi kursi yang dekat dengan charging station untuk mengisi daya smartphone-nya, sehingga bagian timur ini dikatakan sepi penumpang.

Pengamatan perilaku calon penumpang di bagian barat, sama sekali tidak menunjukkan adanya indikasi ketidaknyamanan. Ruang personal yag menyempit disebabkan kondisi kepadatan tinggi, ternyata tidak berpengaruh terhadap kenyamanan. Calon penumpang lebih memilih memperhatikan HP/ Gadget nya ketimbang peduli keadaan sekitarnya. Perbedaan jenis kelamin terbukti tidak menjadi masalah, ketika harus duduk berhimpitan, sekalipun tidak saling mengenal. Perubahan sikap dan raut wajah calon penumpang akan nampak, ketika ada calon penumpang lain yang merokok. Namun keadaan ini segera membaik, dengan teguran penumpang lain, dan kesadaran calon penumpang yang merokok untuk memilih tempat duduk khusus untuk yang merokok. Pengelola stasiun menyediakan ruang tunggu khusus untuk calon penumpang yang merokok, yaitu pada sisi paling barat stasiun.

Berdasarkan skema pemetaan pola perilaku pada ruang tunggu Stasiun Purwosari diperoleh hasil sebagai berikut:

1. Calon Penumpang cenderung lebih banyak yang bermain HP / Gadget-nya.

2. Sebagian besar Penumpang lebih memilih duduk di dekat charging station.

3. Penumpang Kereta Prameks cenderung masuk lebih awal untuk duduk di bagian depan ruang tunggu.

4. Calon Penumpang cenderung memenuhi ruang tunggu sebelah barat karena lebih dekat dengan pintu masuk pemeriksaan tiket/boarding pass. 
5. Calon penumpang yang duduk di ruang tunggu bagian tengah lebih sedikit dibandingkan calon penumpang pada bagian ruang tunggu barat maupun timur.

6. Pada ruang tunggu bagian timur terdapat lebih sedikit calon penumpang dibandingkan bagian tengah dan timur.

Berdasarkan pengamatan, terdapat beragam aktivitas dengan jumlah pelaku, sebagaimana tabel 1 berikut ini:

Table 1. Hasil Survey

\begin{tabular}{c|l|c}
\hline No. & \multicolumn{1}{|c|}{ Pola Keberagaman Perilaku } & Jumlah \\
\hline $\mathbf{1}$ & Mengisi daya smartphone & 27 \\
$\mathbf{2}$ & Main HP / Gadget (music, game, foto- & 40 \\
$\mathbf{3}$ & foto, dsb.) & Membaca buku \\
$\mathbf{4}$ & Tidur & 6 \\
$\mathbf{5}$ & Mengobrol/Berinteraksi dengan & 11 \\
$\mathbf{6}$ & penumpang lain & 28 \\
\hline \multicolumn{2}{c}{ Lain-Lain (kegiatan semu) } & 38 \\
\hline
\end{tabular}

(sumber: Data penulis, 2018)

Prosentase aktivitas calon penumpang ketika menunggu jadwal keberangkatan kereta api Prameks, yang terbanyak adalah bermain HP/gadget sejumlah $27 \%$ dan aktivitas membaca buku adalah yang paling sedikit dilakukan oleh calon penumpang sejumlah $4 \%$. Adapun aktivitas lain dapat terlihat dalam gambar 4 berikut:

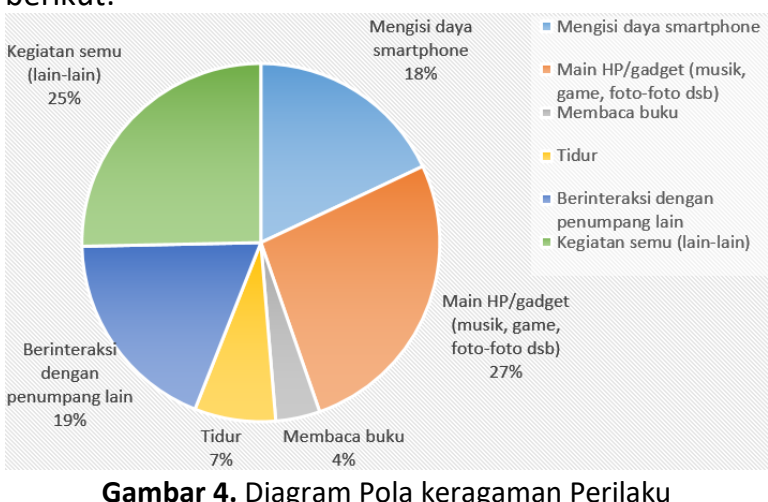

Gambar 4. Diagram Pola keragaman Perilaku (sumber: Dokumen Penulis, 2019)

Gambar berikut adalah suasana di ruang tunggu, ketika calon penumpang menunggu kedatangan kereta api Prameks, yang akan membawanya ke tempat tujuan:
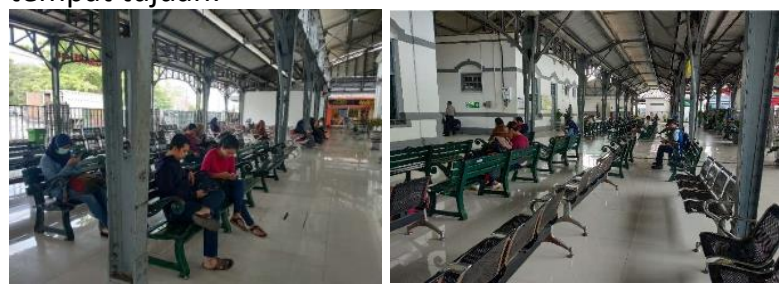

Gambar 5. Suasana di ruang tunggu bagian tengah (sumber: dokumen penulis, 2018)

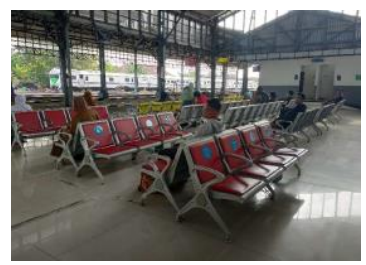

(a)

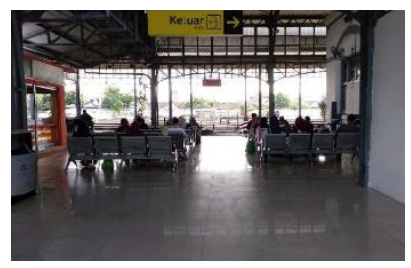

(b)
Gambar 6. Suasana di ruang tunggu (a) sebelah timur dan (b) sebelah barat (sumber: dokumen penulis, 2018)

Beberapa penjelasan pola keragaman perilaku sebagai berikut:

1. Mengisi daya Smartphone (18\%) : calon penumpang memilih duduk di dekat charging station atau tempat duduk yang berada dekat dengan stop kontak listrik untuk mengisi baterai Smartphone nya. Didominasi oleh mahasiswa dan pekerja.

2. Main HP / Gadget (27\%) : calon penumpang yang menggunakan Smartphone, kamera, gadget, dan sebagainya tanpa mengisi daya untuk menghabiskan waktu menunggu datangnya kereta.

3. Membaca Buku (4\%) : pola perilaku ini di dominasi oleh mashaiswa/l yang menghabiskan waktunya membaca buku untuk menunggu datangnya kereta.

4. Tidur (7\%) : dikarenakan penulis melakukan survey pada saat bulan puasa menjelang Lebaran, tidur menjadi pola perilaku yang umum dilakukan oleh para calon penumpang.

5. Mengngobrol / Berinteraksi dengan penumpang lain (19\%) : pola perilaku dimana terjadi aktivitas sosial antara satu penumpang dengan penumpang lain.

6. Lain-lain (kegiatan semu) (25\%) : macam-macam atau gabungan kegiatan sehari-hari yang tidak terlalu sering terjadi dan tidak terlalu konsisten seperti, pergi ke toilet, ke mushola, merapikan barang bawaan, dan sebagainya.

\section{KESIMPULAN}

Dari hasil analisis data yang telah di dapatkan serta pengamatan di Ruang Tunggu Stasiun Purwosari dapat disimpulkan beberapa poin penting, adalah sebagai berikut:

1. Sirkulasi pada ruang tunggu paling padat terdapat pada ruang tunggu bagian barat, sedangkan pada bagian tengah pengunjung sedang/cukup ramai, dan pada bagian barat hanya terdapat sedikit calon penumpang kereta Prameks. Ruang tunggu bagian barat adalah terdekat dari pintu masuk/pintu pemeriksaan tiket. Terdapat kecenderungan orang untuk mencari kemudahan dan merasa cukup nyaman 
dengan keadaan yang mudah dicapai tersebut, walaupun ruang personalnya semakin menyempit, karena padatnya calon penumpang.

2. Pola sirkulasi calon penumpang cenderung sedikit, hanya sebatas masuk stasiun, menunggu kereta api Prameks datang, lalu masuk kereta. Calon penumpang umumya datang di stasiun mendekati jadwal keberangatan kereta.

3. Kegiatan yang berada pada ruang tunggu Stasiun Purwosari sangat beragam, banyak hal yang dilakukan di area rung tunggu seperti: bermain Smartphone, mengisi daya smartphone, bersosialisasi, menunggu kereta, tidur, main game, mendengarkan music dengan headset, baca koran, baca buku, baca novel dan sebagainya. Perilaku terbanyak adalah bermain Smartphone.

4. Pola perilaku calon penumpang kereta Prameks cenderung tidak menyimpang karena keamanan dan kebersihan stasiun sangat terjaga.

Keadaan kuantitas dan kualitas perilaku calon penumpang, disarankan Stasiun Purwosari menambah kapasitas ruang tunggu bagian barat, karena pada bagian tersebut paling banyak calon penumpang Kereta Prameks, sementara kursi ruang tunggu sangat terbatas.

\section{DAFTAR PUSTAKA}

Harjono, S. H. (2016, Agustus 31). Kompasiana. Retrieved Januari 12, 2018, from Menyusuri Stasiun Purwosari, Stasiun Kereta Api Tertua di Kota Solo: https://www.kompasiana.com/sucihistiraludin/ 57c697e93197733c43951a09/menyusuristasiun-purwosari-stasiun-kereta-api-tertua-dikota-solo?page=all

Himawan, M. G. (2018). Persepsi Ruang Personal Pengguna Fasilitas Ruang Tunggu Stasiun Gubeng. Surabaya: Program Studi Psikologi Fakultas Psikologi dan Kesehatan UIN Sunan Ampel.

Rapoport, A., 1977. Human aspects of urban form: towards a man environment approach to urban form and design. Elsevier.

Sommer, R., 1969. Personal Space. The Behavioral Basis of Design.

https://id.wikipedia.org/wiki/Kategori:Stasiun k ereta api kelas besar

Undang-undang RI tentang Perkeretaapian Nomor 13 Tahun 1992 